\title{
Strengthening Cross River state schools of nursing and midwifery by updating their training curricula, procedure manuals and student handbooks
}

\author{
Ekechi Okereke \\ Population Council \\ Godwin Unumeri \\ Population Council \\ Aisha Jibril \\ Population Council
}

Follow this and additional works at: https://knowledgecommons.popcouncil.org/departments_sbsr-rh

Part of the Family, Life Course, and Society Commons, International Public Health Commons, Maternal and Child Health Commons, Nursing Midwifery Commons, and the Women's Health Commons How does access to this work benefit you? Let us know!

\section{Recommended Citation}

Okereke, Ekechi, Godwin Unumeri, and Aisha Jibril. 2019. "Strengthening Cross River state schools of nursing and midwifery by updating their training curricula, procedure manuals and student handbooks," project brief. Abuja: Population Council. 


\section{OF NURSING AND MIDWIFERY BY UPDATING THEIR TRAINING CURRICULA, PROCEDURE MANUALS AND STUDENT HANDBOOKS}

\section{INTRODUCTION}

Many of Nigeria's Nursing and Midwifery schools and colleges encounter challenges that include outdated training curricula, which can lead, in some cases, to loss of accreditation.

Training health care workers is a health training institution core function ${ }^{1,2}$. Nigeria's health training institutions include colleges or schools specifically for nurse and midwife training, supervised by their respective regulatory bodies ${ }^{3}$. Nigeria's nursing and midwifery institutions are supervised by the Nursing and Midwifery Council of Nigeria (NMCN), which stipulates minimum standards of compliance for accreditation.

\section{BACKGROUND}

Although Nigeria's Cross River state has three Nursing schools (in Itigidi, Ogoja and Calabar) and three Midwifery schools (School of Midwifery Calabar, School of Basic Midwifery Obudu and School of Post-Basic Midwifery Monaiya-Ogoja), in 2014 its only health training institution with accreditation-which was provisional-was the School of Post-Basic Midwifery MonaiyaOgoja. The other five institutions had lost their accreditations from NMCN.

NMCN's accreditation assessment team listed numerous factors leading to the schools' accreditation losses, including inadequate infrastructures and lack of tutors. Sub-standard training documents-curricula, procedure, and student manuals-were referenced as well. Documents were outdated, not reflecting current NMCN recommendations. These losses of accreditation and outdated training documents by Cross River's schools of Nursing and Midwifery were issues to be addressed by the Human Resources for Health project.

\section{ADAPTING AND UPDATING CROSS RIVER SCHOOLS OF NURSING AND MIDWIFERY TRAINING CURRICULA, PROCEDURE MANUALS, AND STUDENT HANDBOOKS}

Population Council discussed its planned support through the HRH project with NMCN and Cross River's six schools of Nursing and Midwifery. NMCN's accreditation team had produced a report addressing key gaps at these health training institutions.
This HRH project, Enhancing the Ability of Frontline Health Workers to Improve Health in Nigeria, is a health systems-strengthening project implemented in Nigeria by Population Council, Global Health Workforce Alliance (GHWA), and the World Health Organization (WHO).

Funded by Global Affairs Canada (GAC), the project began in 2014 in two states, Cross River and Bauchi.

The HRH project works through the federal Ministry of Health and regulatory bodies, specifically NMCN and the Community Health Practitioners' Registration Board of Nigeria (CHPRBN), in addition to the pre-service health training institutions in the project states.

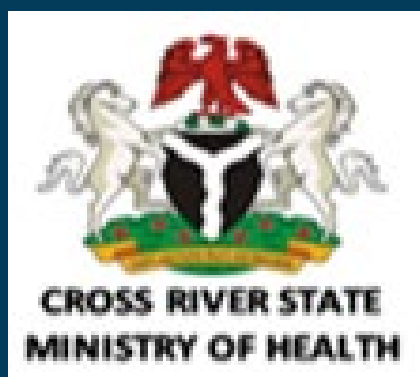


An assessment team led by the Director of Nursing of Calabar's Ministry of Health visited the Cross River schools to determine the best ways of addressing the gaps in the accreditation team's report.

A key strategy was to adapt and update all training curricula, procedure manuals, and student handbooks to reflect current NMCN recommendations. With key Ministry officials, the Council identified suitable curriculum experts to review the accreditation team's report, with emphasis on adapting and updating the training curricula, manuals, and handbooks.

Each school's curriculum review committee was reconstituted, with new members, improved capacities, and regular meetings. Review meetings with curriculum experts, Ministry officials, as well as Council staff adapted and updated existing training curricula, manuals, and handbooks to ensure they reflected current standards, as well as international best practices in addition to Nigerian national policies such as the task shifting and -sharing policy.

Draft documents from the committee meetings were sent to NMCN for its recommendations. Validation meetings with curriculum review committee members, Ministry and NMCN officials, curriculum experts, and Council staff finalized the documents for printing and distribution to each school for NMCN accreditation.

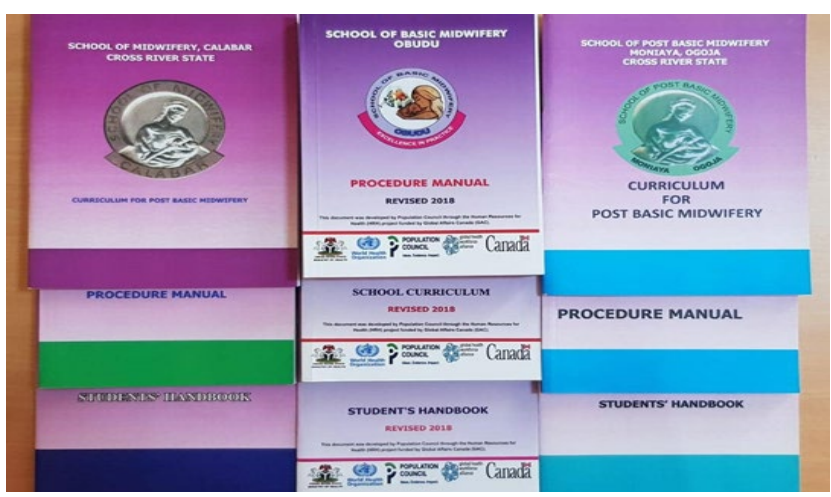

Curricula, manuals, and handbooks for Cross River Midwifery schools

\section{SECURING ACCREDITATION AND CURRICULUM REVIEW COMMITTEE STRENGTHENING}

Due to HRH project efforts, all of Cross River's schools of Nursing and Midwifery are now accredited by NMCN. In 2016 Itigidi School of Nursing and Calabar School of Midwifery secured provisional accreditation, and with Monaiya-Ogoja School of Midwifery, began to admit, train, and officially graduate students. Two years later, with continuing $\mathrm{HRH}$ project support, all three of those schools secured full NMCN accreditation.
The remaining schools-Ogoja School of Nursing, Calabar School of Nursing, and Obudu School of Midwifery-were provisionally accredited. These provisionally accredited schools are each progressing towards full accreditation.

These schools' curriculum review committees now hold regular meetings to review their training curricula, manuals, and handbooks, and consider student and tutor comments. The HRH project's efforts with these committees will be sustained beyond the project because of sustained capacitybuilding and mentoring provided by the Council.

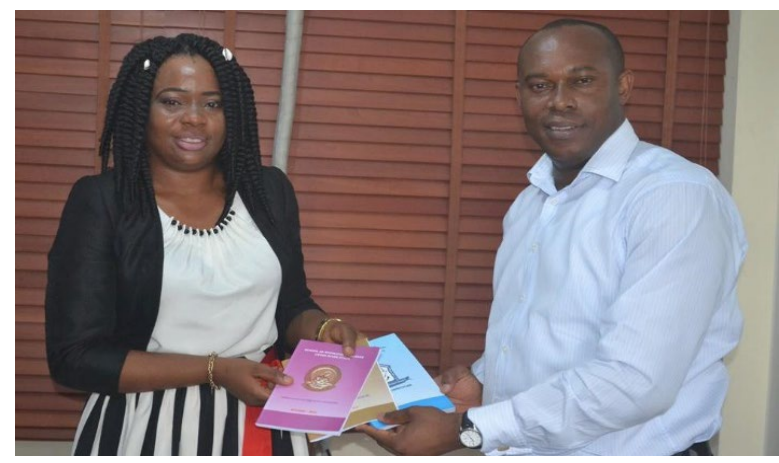

Cross River training curricula presented to Dr. Asibong, Commissioner for Health, by the HRH Project Director

\section{CONCLUSION}

Adequate standards for the curricula, procedure manuals, and student handbooks of health training institutions are required for the effective training of key frontline health care providers, such as nurses and midwives, to address the high maternal, newborn and child health morbidity and mortality in Nigeria. It is important that this is a collaborative process involving NMCN along with training institutions' management teams and curriculum review committee members.

\section{CITATIONS}

1. World Health Organization. 2010. Guidelines on Quality Assurance and Accreditation of Nursing and Midwifery Educational Institutions. Geneva: WHO.

2. World Health Organization. 2013. Transforming and Scaling Up Health Professional Education and Training. Policy Brief on Regulation of Health Professional Education. Geneva: WHO.

3. Essel HB, M Boakye-Yiadom, S Mohammed. 2018. Internal Quality Assurance Practices of Nursing and Midwifery Training Colleges and the Role of Regulatory Bodies: The Perspectives of Health Tutors. Journal of Nursing Education and Practice 8(10).

\section{CONTACT US}

Ekechi Okereke HRH Project Director Population Council Nigeria eokereke@popcouncil.org
Aisha Jibril

Program Officer

Population Council Nigeria ajibril@popcouncil.org
Godwin Unumeri

HRH Program Administrator, Cross River

Population Council Nigeria gunumeri@popcouncil.org 